\title{
PAX genes in cancer; friends or foes?
}

\author{
Caiyun G. Li $^{1}$ and Michael R. Eccles ${ }^{2 *}$ \\ 1 Department of Pediatrics, Stanford University School of Medicine, Stanford, CA, USA \\ ${ }^{2}$ Developmental Genetics and Pathology Laboratory, Department of Pathology, Dunedin School of Medicine, University of Otago, Dunedin, New Zealand
}

\section{Edited by:}

Ashani Weeraratna, The Wistar

Institute, USA

Reviewed by:

Nhan Le Tran, Translational Genomics

Research Institute, USA

Keith Hoek, University of Zürich,

Switzerland

Michael O'Connell, The Wistar

Institute, USA

${ }^{*}$ Correspondence:

Michael R. Eccles, Department of Pathology, Dunedin School of

Medicine, University of Otago, P.O.

Box 913, Dunedin, New Zealand.

e-mail:michael.eccles@otago.ac.nz
PAX genes have been shown to be critically required for the development of specific tissues and organs during embryogenesis. In addition, PAX genes are expressed in a handful of adult tissues where they are thought to play important roles, usually different from those in embryogenesis. A common theme in adult tissues is a requirement for PAX gene expression in adult stem cell maintenance or tissue regeneration. The connections between adult stem cell PAX gene expression and cancer are intriguing, and the literature is replete with examples of PAX gene expression in either situation. Here we systematically review the literature and present an overview of postnatal PAX gene expression in normal and cancerous tissue. We discuss the potential link between PAX gene expression in adult tissue and cancer. In addition, we discuss whether persistent PAX gene expression in cancer is favorable or unfavorable.

Keywords: PAX, cancer, stem cell, proliferation, differentiation, cell cycle

\section{INTRODUCTION}

The PAX/Pax (paired box) gene family is now recognized as potentially playing important roles in cancer progression (reviewed in Robson et al., 2006). The family comprises nine transcription factors in humans (PAX1-PAX9) and mice (Paxl-Pax9) that are often described as cell-lineage-specific regulators of tissues where their expression is normally found. PAX gene family members share highly similar structural motifs, evolutionarily conserved among orthologs present in worms, flies, frogs, fish, and birds (Vorobyov and Horst, 2006). Relationships between PAX genes in terms of their sequence homologies and evolutionary phylogeny are shown in Figure 1. The pivotal roles of Pax during development are further exemplified by loss-of-function Pax mutant mouse models, many of which demonstrate prenatal or early postnatal lethality (reviewed in Wang et al., 2008). The expression and role of Pax genes during embryogenesis and tumorigenesis has previously been reviewed extensively (Chi and Epstein, 2002; Robson et al., 2006; Wang et al., 2008). However, upon completion of organogenesis the expression of most Pax genes attenuates, while in some tissues Pax gene expression either continues into adultlife or re-expression is possible (Table 1). The presence of Pax gene expression in adult tissues is often linked with stem cell-like properties and tissue repair, depending on the tissue context (see below). Although features of Pax expression in adult tissues may potentially confer significant functions on specific cells in these tissues, their specific roles in adult tissue in many cases remain largely unexplored. With their expression profiles often finely tuned both spatially and temporally, one would predict that deregulated Pax gene expression could therefore disrupt tissue homeostasis and contribute to diseases such as cancer (Maulbecker and Gruss, 1993; Muratovska et al., 2003).

Each of the nine $P A X$ family members has been associated with multiple cancer types (Robson et al., 2006). PAX gene expression is often found in cancer types that originate from tissues that require
$P A X$ gene expression during development or in homeostasis (see Table 1). Together, these data suggest that $P A X$ gene expression may be deregulated in cancer, but at least in some cases $P A X$ gene expression is a carry-over of normal expression in normal adult tissues. It is now clear that $P A X$ genes can either promote or inhibit tumorigenesis. This minireview will focus on specific examples of the role of $P A X$ gene expression in adult tissues and $P A X$ gene expression in cancer. In addition, we will discuss evidence supporting hypothesized functions of $P A X$ gene expression in cancer.

\section{PAX EXPRESSION IN ADULT TISSUES AND IN CANCER}

$P A X$ gene expression is relatively uncommon in adult tissues, and re-expression occurs only under certain circumstances. Pax gene knockout mice generally die either prenatally or soon after birth (Wang et al., 2008), which creates difficulties for investigating Pax gene functions in adult tissues unless conditional or tissue-specific knockouts are available. In some cases (i.e., Pax2, Pax3, and Pax6) Pax genes demonstrate haploinsufficiency (Epstein et al., 1991; Hill et al., 1991; Favor et al., 1996), and research has focused on their functions in adult tissues using heterozygous Pax mouse models (see below). PAX gene expression in adult tissues is often associated with tissue homeostasis. Table 1 summarizes current knowledge of $P A X$ gene expression in adult tissues. There are two main types: (1) continuing expression from organogenesis, and (2) recurring expression under certain physiological conditions. During embryogenesis and in adult tissues a frequent role of $P A X$ gene expression appears to be to maintain stem or progenitor cell state (plasticity) before cells fully commit to their fate, whether this is during organogenesis, or in tissue regeneration. However, the exact role that $P A X$ expression plays in stem cell maintenance is not yet clear, but one possibility that we discuss below is that PAX8 might maintain the capacity of cells to enter the cell cycle, whilst simultaneously inhibiting senescence (Li et al., 2011a). 


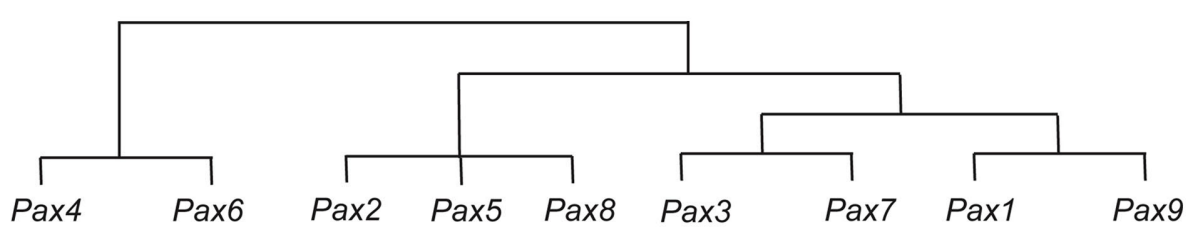

FIGURE 1 | Representation of sequence similarities between the Pax genes, and their possible evolution. It is thought that the Pax4 and Pax6 genes are derived from an early ancestral Pax gene, and that from this ancestral Pax gene the ancestor of the Pax2, Pax5, and Pax 8 genes was subsequently derived, followed by the ancestors of the Pax 3 and Pax 7 genes, and the Pax1 and Pax9 genes (Miller, 1999).

Table 1 | Continuing and recurring expression of $P A X$ genes in adult tissues.

\begin{tabular}{|c|c|c|c|}
\hline Gene & Continuing expression & Recurring expression* & Reference \\
\hline$P A X 1$ & Thymus & - & Peters et al. (1995), Wallin et al. (1996) \\
\hline PAX2 & $\begin{array}{l}\text { Brain, pancreas, eye, female genital tract, } \\
\text { breast, lymphocytes }\end{array}$ & Kidney, prostate & $\begin{array}{l}\text { Stoykova and Gruss (1994), Ritz-Laser et al. (2000), Chu et al. (2001), } \\
\text { Silberstein et al. (2002), Tong et al. (2006, 2007), Chen et al. (2010) }\end{array}$ \\
\hline PAX3 & Brain, skin, skeletal muscle & - & Stoykova and Gruss (1994), Relaix et al. (2006), He et al. (2010) \\
\hline PAX4 & - & Pancreas, eye, pineal gland & Brun et al. (2004), Rath et al. (2009a,b) \\
\hline PAX5 & Brain, B-lymphocytes, lung, testis & - & Stoykova and Gruss (1994), Nutt et al. (1997), Adams et al. (1992) \\
\hline PAX6 & Brain, pancreas & Eye, brain (olfactory) & Stoykova and Gruss (1994), Sivak et al. (2000), Guo et al. (2010) \\
\hline PAX7 & Brain, skeletal muscle & - & Stoykova and Gruss (1994), Relaix et al. (2006) \\
\hline PAX8 & $\begin{array}{l}\text { Thyroid, kidney, placenta, female genital } \\
\text { tract, lymphocytes }\end{array}$ & Pancreas & $\begin{array}{l}\text { Zannini et al. (1992), Ferretti et al. (2005), Rieck et al. (2009), Tong et al. } \\
\text { (2009), Ozcan et al. (2011) }\end{array}$ \\
\hline PAX9 & Thymus, esophagus & - & Peters et al. (1995) \\
\hline
\end{tabular}

${ }^{*}$ Recurring expression includes minimally detected expression.

\section{PAX1}

Pax 1 is expressed in a small fraction of cortical cells in the adult thymus (Peters et al., 1995; Wallin et al., 1996), where it is required for the maturation of thymocytes. Expression of Paxl in adult thymus epithelium promotes the thymus microenvironment required for normal T cell maturation.

In cervical cancer tissues $P A X 1$ was one of six genes that were shown to be hypermethylated (Lai et al., 2008). Moreover, parallel testing for human papillomavirus (HPV) and PAX1 methylation status in cervical swabs conferred an improved sensitivity than HPV testing alone.

\section{PAX2}

PAX2 is expressed in the medullary regions of adult kidneys, and in the transitional urothelium of the ureter and bladder wall (Tong et al., 2006). PAX2 is also expressed in the epithelial lining of the fallopian tube in females (Tong et al., 2007) and in the epithelium of the male genital tract from the Rete testis to the ejaculatory duct (Tong et al., 2011). In female mice, Pax2 is expressed during puberty in the mammary tubular epithelium (Silberstein et al., 2002), and is required for progesterone-dependent mammary development (Silberstein et al., 2002). PAX2 participates as part of a complex with estrogen receptor to regulate the ERBB2 promoter (Hurtado et al., 2008).

In addition, PAX2 is expressed in the glucagon-expressing cells of the pancreas (Ritz-Laser et al., 2000), and Pax2 expression has been demonstrated in the optic tectum in mice (Nakamura, 2001). Recurring Pax gene expression is important for tissue repair and regeneration. While embryonic Pax2 gene expression has already largely attenuated in the adult kidney cortex, four independent groups have demonstrated that upon kidney injury, Pax2 expression re-emerges at the initial stage of tubular regeneration, in a transient and temporally restricted pattern. The recurring expression is also proposed to confer a protective function, preventing tubular cells from apoptosis in the initial stage of regeneration (Imgrund et al., 1999; Maeshima et al., 2002; Cohen et al., 2007; Huang et al., 2011). Chen et al. (2010) have also shown that androgen-dependent re-expression of Pax2 occurs after castration in male mice.

PAX2 is expressed in ovarian cancers, in renal cell carcinomas (RCC), and in some bladder carcinomas (Muratovska et al., 2003; Tong et al., 2007; Herlitz et al., 2008). In these cell types it appears to be important for tumor cell survival (Muratovska et al., 2003; Hueber et al., 2006), which has recently been shown to be because PAX2 regulates ADAM10 (Doberstein et al., 2011), and in RCC PAX2 expression is promoted by the loss of VHL and hypoxia (Luu et al., 2009).

PAX2 is also expressed in breast cancer (Silberstein et al., 2002), where it is important for maintaining the estrogen receptor responsiveness of breast cancer. In breast cancer cells an estrogen receptor-PAX2 complex regulates ERBB2, and determines response to tamoxifen (Hurtado et al., 2008). In addition, PAX2 expression is required for tamoxifen-induced endometrial carcinogenesis (Wu et al., 2005), and loss of PAX2 expression enhances endometrial cancer malignancy (Monte et al., 2010; Roh et al., 2010). Aberrant expression of PAX2 has also been observed in 
prostate cancer (Khoubehi et al., 2001). In addition, PAX2 expression is associated with resistance to apoptosis in Kaposi's sarcoma cells (Buttiglieri et al., 2004).

\section{PAX3}

Pax3 is expressed in a pool of stem cells in adult muscle, called satellite cells (reviewed in Buckingham and Relaix, 2007). The Pax3 gene is also expressed in melanocyte stem cells (melanoblasts) localized in the bulge region of hair follicles in adult skin (Lang et al., 2005). In this location Pax3 is involved in a transcriptional regulatory network to maintain the undifferentiated state of the melanocyte stem cells (Lang et al., 2005). Interestingly, PAX3 is also expressed in adult human epidermal melanocytes (He et al., 2010; Medic and Ziman, 2010), but in this location it appears PAX3 has retained only some of its developmental roles.

$P A X 3$ undergoes chromosome rearrangement with FOXO1 in the majority of alveolar rhabdomyosarcomas (Galili et al., 1993; Bennicelli et al., 1999). In addition, PAX3 is persistently expressed in embryonal rhabdomyosarcomas (Frascella et al., 1998). PAX3 expression has been reported in melanomas (Scholl et al., 2001; He et al., 2010), where it was initially thought that PAX3 expression is required for the regulation of MITF gene expression, as in the developing neural crest (reviewed in Kubic et al., 2008). MITF is a dominant regulator in the maintenance of plasticity during differentiation in both eye and melanoblast development (Jackson and Raymond, 1994). In both eye and melanocyte precursors Pax2, Pax3, and Pax6 have been shown to transcriptionally activate the Mitf promoter activity (Watanabe et al., 1998; Baumer et al., 2003). Indeed, Pax3-Mitf genetic interactions were shown to act as a nodal point for maintaining embryonic and adult stem cell plasticity (Lang et al., 2005). However, the silencing of PAX3 expression in metastatic melanoma cells had unexpectedly little or no effect on MITF mRNA and protein expression (He et al., 2011), and indeed PAX3 was only minimally bound to the MITF promoter in melanoma cells (Medic and Ziman, 2010).

\section{PAX4}

Although there has been a lack of studies relating to the association of Pax4 in both adult and cancer tissues, two independent studies have reported that Pax4 re-expression confers a protective function in pancreatic $\beta$-cells (Brun et al., 2004; Lu et al., 2007). The mitogen induced Pax4 expression not only increased $\beta$-cell replicative potential, it also protects cells from apoptosis, through transcriptionally activating both the oncogene $c-m y c$ and the anti-apoptotic gene $B c l-x L$ expression, respectively (Brun et al., 2004).

PAX4 expression was shown to be upregulated in human insulinomas (Miyamoto et al., 2001), and was proposed to be a survival factor in rat insulinoma cells, through upregulating $B c l-x l$ expression (Brun et al., 2007). In contrast, ectopic PAX4 expression in melanoma reduced cell growth, which suggested a possible tumor suppressor role in melanoma (Hata et al., 2008).

\section{PAX5}

PAX5 is expressed during B lymphopoiesis, and plays an essential role in early $B$, pre-B and pro-B lymphocyte development, particularly in the developmental pathway controlling V-to-DJ recombination (Nutt et al., 1997; Sanz et al., 2003). Interestingly, re-programming of mature B-cells to pluripotency requires PAX5 knockdown in addition to expression of Oct4, Sox2, Klf4, and c-Myc (Hanna et al., 2008).

PAX5 expression is observed in most B-cell neoplasms, including B-cell lymphoma (Krenacs et al., 1998). In contrast, PAX5 haploinsufficiency synergizes with STAT5 activation to induce acute lymphoblastic leukemia (Heltemes-Harris et al., 2011). In hepatocellular carcinoma PAX5 has been identified as a novel tumor suppressor through interacting with the p53 signaling pathway (Liu et al., 2011). Consistent with this, overexpression of PAX5 induces apoptosis in multiple myeloma cells (Proulx et al., 2010). PAX5 is expressed in medulloblastoma (Kozmik et al., 1995), and in a sub-type of neuroblastoma (Baumann Kubetzko et al., 2004), perhaps reflecting the earlier requirement for PAX5 expression in the mid/hindbrain boundary during embryogenesis (Urbanek et al., 1994). PAX5 expression in breast cancer cells enhances epithelial behavior (Vidal et al., 2010), and has been associated with a significantly better prognosis than breast cancers where PAX5 is not expressed.

\section{PAX6}

Pax6 is re-expressed in the corneal epithelium during corneal wound repair (Sivak et al., 2000). However deficiency of Pax6 expression during corneal wound repair is correlated with reduced cornea epithelial cell adhesion, elevated cell proliferation, increased stromal cells apoptosis (Ramaesh et al., 2005, 2006; Ou et al., 2010), and defective corneal neuronal migration (Leiper et al., 2009), suggesting that Pax6 suppresses proliferation and enhances differentiation. Similarly, during olfactory epithelial regeneration, Pax6 gene expression is transiently elevated in globose basal cells, which comprise the putative stem cell pool to commit to either neuronal and epithelial cell lineages during regeneration (Guo et al., 2010). PAX6 has been referred to as a neuroectoderm cell fate determinant (Zhang et al., 2010). Interestingly it was shown that PAX6 protein level is essential for controlling the balance between neural stem cell self-renewal and neurogenesis (Sansom et al., 2009).

In the early stages of bladder cancer, and in invasive breast cancer, $P A X 6$-associated CpG islands become progressively hypermethylated, and this is associated with increased PAX6 expression (Salem et al., 2000; Hellwinkel et al., 2008; Moelans et al., 2011). PAX6 expression was shown to suppress the growth of human glioblastoma cells (Zhou et al., 2005), suppressing their invasiveness and expression of matrix-metalloproteinase 2 (Mayes et al., 2006), and increasing glioma cell susceptibility to detachment and oxidative stress (Chang et al., 2007), as well as reducing angiogenesis (Zhou et al., 2010). However, PAX6 was not apparently mutated in gliomas (Pinto et al., 2007). In contrast, PAX6 was expressed in pancreatic adenocarcinoma, downregulated upon terminal differentiation (Lang et al., 2008), and actively participated in cancer progression through activation of the MET tyrosine kinase receptor gene (Mascarenhas et al., 2009). In addition, endogenous and lentiviral-mediated PAX6 expression promoted cell proliferation and inhibited apoptosis in retinoblastoma cells (Bai et al., 2011; Li et al., 2011b), as well as promoting 
breast cancer cell proliferation and tumorigenesis (Zong et al., 2011).

\section{PAX7}

In adult muscle Pax7 is expressed in the muscle satellite cells, a stem cell pool. The satellite cells are required for tissue repair and regeneration following muscle injury (reviewed in Buckingham and Relaix, 2007), and Pax7 expression is required to maintain survival and proliferation of postnatal satellite cells (Relaix et al., 2006).

PAX7 undergoes chromosome rearrangement with FOXO1 in alveolar rhabdomyosarcomas, in a similar fashion to, although less frequently than PAX3 (Galili et al., 1993; Bennicelli et al., 1999).

\section{PAX8}

PAX8 is expressed in the adult thyroid and kidney (Zannini et al., 1992; Tong et al., 2009), and its role in adult thyroid tissue remains the same as in the developing thyroid; regulating $T g$ (thyroglobulin), Tpo (thyroid peroxidase), and NIS (sodium/iodide symporter) expression, all of which are essential for thyroid hormone synthesis (reviewed in De Felice and Di Lauro, 2011). Interestingly, Oct4 expression, a stem cell marker in adult thyroid, coincides with a subset of Pax8 positive cells, but not Tg positive cells (which represent differentiated cells; Thomas et al., 2006). These observations suggest that Pax8 has a separate role in the maintenance of adult thyroid stem or progenitor cells. Similarly, in adult kidneys PAX8 is expressed in the Bowman's capsule, and in medullary regions (Tong et al., 2009; Li et al., 2011a), which have been proposed to be sites of renal stem and/or progenitor cells (reviewed in Little and Bertram, 2009), although the functional role of PAX8 in the adult kidney has yet to be explored.

$P A X 8$ undergoes chromosome rearrangement with PPAR $\gamma$ in thyroid adenocarcinomas (Kroll et al., 2000). PAX8 was also identified in a systematic screen as a lineage survival factor for ovarian cancer cells (Hibbs et al., 2004; Bowen et al., 2007; Cheung et al., 2011), possibly relating to its critical role during the development of the fetal Mullerian duct (Mittag et al., 2007). In renal, ovarian and thyroid cancers, we recently showed that PAX8 is required for basal E2F1 transcription and thus the capacity for entry into the cell cycle, and also for maintaining the stability of its transcriptional c-factor, RB (Li et al., 2011a). Either overexpression or loss of E2F1 ultimately results in apoptosis or senescence (Qin et al., 1994; Dimri et al., 2000; Berton et al., 2005; Park et al., 2006), potentially explaining why senescence is observed when PAX8 expression is knocked down using siRNAs in cancer cell lines. Expression of

\section{REFERENCES}

Adams, B., Dorfler, P., Aguzzi, A., Kozmik, Z., Urbanek, P., MaurerFogy, I., and Busslinger, M. (1992). Pax-5 encodes the transcription factor BSAP and is expressed in $\mathrm{B}$ lymphocytes, the developing CNS, and adult testis. Genes Dev. 6, 1589-1607.

Bai, S. W., Li, B., Zhang, H., Jonas, J. B., Zhao, B. W., Shen, L., and Wang, Y. C. (2011). Pax6 regulates proliferation and apoptosis of human retinoblastoma cells. Invest. Ophthalmol. Vis. Sci. 52, 4560-4570.

Baumann Kubetzko, F. B., Di Paolo, C., Maag, C., Meier, R., Schafer, B. W., Betts, D. R., Stahel, R. A., and Himmelmann, A. (2004). The PAX5 oncogene is expressed in $\mathrm{N}$-type neuroblastoma cells and increases tumorigenicity of a Stype cell line. Carcinogenesis 25, 1839-1846.

Baumer, N., Marquardt, T., Stoykova, A., Spieler, D., Treichel, D.,

PAX8 has also been shown to regulate telomerase, an important factor in cellular aging and immortalization, in glioblastoma cell lines (Chen et al., 2008).

\section{PAX9}

Like Pax1, Pax9 is expressed in the adult thymus (Peters et al., 1995), and Pax9 expression is also required for permanent tooth development (Suda et al., 2011). In addition, PAX9 cDNA has been isolated from adult human esophagus (Peters et al., 1997).

$P A X 9$ expression has been shown to mediate oncogene-induced cell survival in oral squamous cell carcinoma (Lee et al., 2008). On the other hand progressive loss of PAX9 expression correlates with increasing malignancy in esophageal cancers (Gerber et al., 2002). PAX9 was shown to be amplified and highly expressed in lung cancer tissues (Kendall et al., 2007), and in addition, pairwise overexpression of genes within the amplified DNA, including $P A X$, was synergistic in promoting the proliferation of lung cancer cell lines.

\section{CONCLUDING REMARKS}

It is widely accepted that tumor formation is an aberrant form of organogenesis in adult tissues. Although PAX expression is relatively rare in adult tissues, evidence suggests this expression may be involved in maintaining pluripotency and survival of stem cell populations. Either continuing or recurring PAX expression is essential to provide pools of progenitor cells for tissue regeneration upon injury. In cancer cells, achieving self-sufficiency in growth signals and unrestricted replicative potential requires that they are able to survive in potentially adverse microenvironments during tumor progression. There are now numerous studies that imply that $P A X$ genes play important roles in conferring growth and survival advantages to cancer cells, and that they regulate cell plasticity.

Conceptually, proliferation and differentiation are placed at opposite ends of the "spectrum" of tumor progression. Yet, PAX genes, such as $P A X 8$, could play key roles in balancing these processes. Clearly, more studies will be required to better understand the role that PAX genes play in adult tissues and in cancer.

\section{ACKNOWLEDGMENTS}

The authors acknowledge funding from the New Zealand Institute for Cancer Research Trust, the Health Research Council of New Zealand, and the University of Otago Faculty of Medicine Research Trust award.

Ashery-Padan, R., and Gruss, P. (2003). Retinal pigmented epithelium determination requires the redundant activities of $\operatorname{Pax} 2$ and Pax6. Development 130, 2903-2915. Bennicelli, J. L., Advani, S., Schafer, B. W., and Barr, F. G. (1999). PAX3 and PAX7 exhibit conserved cis-acting transcription repression domains and utilize a common gain of function mechanism in alveolar rhabdomyosarcoma. Oncogene 18, 4348-4356.
Berton, T. R., Mitchell, D. L., Guo, R. and Johnson, D. G. (2005). Regulation of epidermal apoptosis and DNA repair by E2F1 in response to ultraviolet B radiation. Oncogene 24, 2449-2460.

Bowen, N. J., Logani, S., Dickerson, E. B., Kapa, L. B., Akhtar, M., Benigno, B. B., and McDonald, J. F. (2007). Emerging roles for PAX8 in ovarian cancer and endosalpingeal development. Gynecol. Oncol. 104, 331-337. 
Brun, T., Duhamel, D. L., Hu He, K. H., Wollheim, C. B., and Gauthier, B. R. (2007). The transcription factor PAX4 acts as a survival gene in INS-1E insulinoma cells. Oncogene 26, 4261-4271.

Brun, T., Franklin, I., St-Onge, L., Biason-Lauber, A., Schoenle, E. J., Wollheim, C. B., and Gauthier, B. R. (2004). The diabetes-linked transcription factor PAX4 promotes $\{$ beta\}-cell proliferation and survival in rat and human islets. J. Cell Biol. 167, 1123-1135.

Buckingham, M., and Relaix, F. (2007). The role of Pax genes in the development of tissues and organs: Pax3 and Pax7 regulate muscle progenitor cell functions. Annu. Rev. Cell Dev. Biol. 23, 645-673.

Buttiglieri, S., Deregibus, M. C., Bravo, S., Cassoni, P., Chiarle, R., Bussolati, B., and Camussi, G. (2004). Role of Pax2 in apoptosis resistance and proinvasive phenotype of Kaposi's sarcoma cells. J. Biol. Chem. 279, 4136-4143.

Chang, J. Y., Hu, Y., Siegel, E., Stanley, L., and Zhou, Y. H. (2007). PAX6 increases glioma cell susceptibility to detachment and oxidative stress. $J$. Neurooncol. 84, 9-19.

Chen, Q., Degraff, D. J., and Sikes, R. A. (2010). The developmental expression profile of PAX2 in the murine prostate. Prostate 70, 654-665.

Chen, Y. J., Campbell, H. G., Wiles, A. K., Eccles, M. R., Reddel, R. R., Braithwaite, A. W., and Royds, J. A. (2008). PAX8 regulates telomerase reverse transcriptase and telomerase RNA component in glioma. Cancer Res. 68, 5724-5732.

Cheung, H. W., Cowley, G. S., Weir, B. A., Boehm, J. S., Rusin, S., Scott, J. A., East, A., Ali, L. D., Lizotte, P. H., Wong, T. C., Jiang, G., Hsiao, J., Mermel, C. H., Getz, G., Barretina, J., Gopal, S., Tomayo, P., Gould, J., Tsherniak, A., Stransky, N., Luo, B., Ren, Y., Drapkin, R., Bhatia, S. N., Meslrov, J. P., Garraway, L. A., Meyerson, M., Lander, E. S., Root, D. E., and Hahn, W. C. (2011). Systematic investigation of genetic vulnerabilities across cancer cell lines reveals lineage-specific dependencies in ovarian cancer. Proc. Natl. Acad. Sci. U.S.A. 108, 12372-12377.

Chi, N., and Epstein, J. A. (2002). Getting your Pax straight: Pax proteins in development and disease. Trends Genet. 18, 41-47.

Chu, Y., Hughes, S., and Chan-Ling, T. (2001). Differentiation and migration of astrocyte precursor cells and astrocytes in human fetal retina: relevance to optic nerve coloboma. FASEB J. 15, 2013-2015.

Cohen, T., Loutochin, O., Amin, M., Capolicchio, J. P., Goodyer, P., and Jednak, R. (2007). PAX2 is reactivated in urinary tract obstruction and partially protects collecting duct cells from programmed cell death. Am. J. Physiol. Renal Physiol. 292, F1267-F1273.

De Felice, M., and Di Lauro, R. (2011). Minireview: intrinsic and extrinsic factors in thyroid gland development: an update. Endocrinology 152, 2948-2956.

Dimri, G. P., Itahana, K., Acosta, M., and Campisi, J. (2000). Regulation of a senescence checkpoint response by the E2F1 transcription factor and p14(ARF) tumor suppressor. Mol. Cell. Biol. 20, 273-285.

Doberstein, K., Pfeilschifter, J., and Gutwein, P. (2011). The transcription factor PAX2 regulates ADAM10 expression in renal cell carcinoma. Carcinogenesis. 32, 1713-1723.

Epstein, D. J., Vekemans, M., and Gros, P. (1991). Splotch (Sp2H), a mutation affecting development of the mouse neural tube, shows a deletion within the paired homeodomain of Pax-3. Cell 67, 767-774.

Favor, J., Sandulache, R., NeuhauserKlaus, A., Pretsch, W., Chatterjee, B., Senft, E., Wurst, W., Blanquet, V., Grimes, P., Sporle, R., and Schughart, K. (1996). The mouse Pax2(1Neu) mutation is identical to a human PAX2 mutation in a family with renal-coloboma syndrome and results in developmental defects of the brain, ear, eye, and kidney. Proc. Natl. Acad. Sci. U.S.A. 93, 13870-13875.

Ferretti, E., Arturi, F., Mattei, T., Scipioni, A., Tell, G., Tosi, E., Presta, I., Morisi, R., Lacroix, L., Gulino, A., Russo, D., Damante, G., and Filetti, S. (2005). Expression, regulation, and function of paired-box gene 8 in the human placenta and placental cancer cell lines. Endocrinology 146, 4009-4015.

Frascella, E., Toffolatti, L., and Rosolen, A. (1998). Normal and rearranged PAX3 expression in human rhabdomyosarcoma. Cancer Genet. Cytogenet. 102, 104-109.

Galili, N., Davis, R. J., Fredericks, W. J., Mukhopadhyay, S., Rauscher, F. J. III, Emanuel, B. S., Rovera, G., and Barr, F. G. (1993). Fusion of a fork head domain gene to $\mathrm{PAX} 3$ in the solid tumour alveolar rhabdomyosarcoma. Nat. Genet. 5, 230-235.

Gerber, J. K., Richter, T., Kremmer, E., Adamski, J., Hofler, H., Balling, R., and Peters, H. (2002). Progressive loss of PAX9 expression correlates with increasing malignancy of dysplastic and cancerous epithelium of the human oesophagus. J. Pathol. 197, 293-297.

Guo, Z., Packard, A., Krolewski, R. C., Harris, M. T., Manglapus, G. L., and Schwob, J. E. (2010). Expression of pax6 and sox 2 in adult olfactory epithelium. J. Comp. Neurol. 518, 4395-4418.

Hanna, J., Markoulaki, S., Schorderet, P., Carey, B. W., Beard, C., Wernig, M., Creyghton, M. P., Steine, E. J. Cassady, J. P., Foreman, R., Lengner, C. J., Dausman, J. A., and Jaenisch, R. (2008). Direct reprogramming of terminally differentiated mature $\mathrm{B}$ lymphocytes to pluripotency. Cell 133, 250-264

Hata, S., Hamada, J., Maeda, K., Murai, T., Tada, M., Furukawa, H., Tsutsumida, A., Saito, A., Yamamoto, Y., and Moriuchi, T. (2008). PAX4 has the potential to function as a tumor suppressor in human melanoma. Int. J. Oncol. 33, 1065-1071.

He, S., Li, C. G., Slobbe, L., Glover, A. Marshall, E., Baguley, B. C., and Eccles, M. R. (2011). PAX3 knockdown in metastatic melanoma cell lines does not reduce MITF expression. Melanoma Res. 21, 24-34.

He, S., Yoon, H. S., Suh, B. J., and Eccles, M. R. (2010). PAX3 is extensively expressed in benign and malignant tissues of the melanocytic lineage in humans. J. Invest. Dermatol. 130, 1465-1468.

Hellwinkel, O. J., Kedia, M., Isbarn, H. Budaus, L., and Friedrich, M. G. (2008). Methylation of the TPEFand PAX6-promoters is increased in early bladder cancer and in norma mucosa adjacent to pTa tumours. BJU Int. 101, 753-757.

Heltemes-Harris, L. M., Willette, M. J., Ramsey, L. B., Qiu, Y. H., Neeley, E. S., Zhang, N., Thomas, D. A., Koeuth, T., Baechler, E. C., Kornblau, S. M., and Farrar, M. A. (2011). Ebf1 or Pax5 haploinsufficiency synergizes with STAT5 activation to initiate acute lymphoblastic leukemia. J. Exp. Med. 208, 1135-1149.

Herlitz, L. C., Tong, G. X., HameleBena, D., and Greenebaum, E. (2008). Nephrogenic adenoma identified on urine cytology using PAX-2 immunostaining. Diagn. Cytopathol. 36, 47-49.

Hibbs, K., Skubitz, K. M., Pambuccian, S. E., Casey, R. C., Burleson, K. M., Oegema, T. R. Jr., Thiele, J. J., Grindle, S. M., Bliss, R. L., and Skubitz, A. P. (2004). Differential gene expression in ovarian carcinoma: identification of potential biomarkers. Am. J. Pathol. 165, 397-414.

Hill, R. E., Favor, J., Hogan, B. L., Ton, C. C., Saunders, G. F., Hanson, I. M., Prosser, J., Jordan, T., Hastie, N. D., and Van Heyningen, V. (1991). Mouse small eye results from mutations in a paired-like homeobox-containing gene. Nature 354, 522-525.

Huang, B., Pi, L., Chen, C., Yuan, F., Zhou, Q., Teng, J., and Jiang, T. (2011). WT1 and Pax2 re-expression is required for epithelial-mesenchymal transition in $5 / 6$ nephrectomized rats and cultured kidney tubular epithelial cells. Cells Tissues Organs (Print). doi:10.1159/000327530. [Epub ahead of print].

Hueber, P. A., Waters, P., Clark, P., Eccles, M., and Goodyer, P. (2006). PAX2 inactivation enhances cisplatin-induced apoptosis in renal carcinoma cells. Kidney Int. 69, 1139-1145.

Hurtado, A., Holmes, K. A., Geistlinger, T. R., Hutcheson, I. R., Nicholson, R. I., Brown, M., Jiang, J., Howat, W. J., Ali, S., and Carroll, J. S. (2008). Regulation of ERBB2 by oestrogen receptor-PAX2 determines response to tamoxifen. Nature 456, 663-666.

Imgrund, M., Grone, E., Grone, H. J., Kretzler, M., Holzman, L., Schlondorff, D., and Rothenpieler, U. W. (1999). Re-expression of the developmental gene Pax-2 during experimental acute tubular necrosis in mice 1. Kidney Int. 56, 1423-1431.

Jackson, I. J., and Raymond, S. (1994). Manifestations of microphthalmia. Nat. Genet. 8, 209-210.

Kendall, J., Liu, Q., Bakleh, A., Krasnitz, A., Nguyen, K. C., Lakshmi, B. Gerald, W. L., Powers, S., and Mu, D. (2007). Oncogenic cooperation and coamplification of developmental transcription factor genes in lung cancer. Proc. Natl. Acad. Sci. U.S.A. 104, 16663-16668.

Khoubehi, B., Kessling, A. M., Adshead, J. M., Smith, G. L., Smith, R. D. and Ogden, C. W. (2001). Expression of the developmental and oncogenic PAX2 gene in human prostate cancer. J. Urol. 165, 2115-2120.

Kozmik, Z., Sure, U., Ruedi, D., Busslinger, M., and Aguzzi, A. (1995). Deregulated expression of PAX5 in medulloblastoma. Proc. Natl. Acad. Sci. U.S.A. 92, 5709-5713.

Krenacs, L., Himmelmann, A. W., Quintanilla-Martinez, L., Fest, T., Riva, A., Wellmann, A., Bagdi, E., Kehrl, J. H., Jaffe, E. S., 
and Raffeld, M. (1998). Transcription factor B-cell-specific activator protein (BSAP) is differentially expressed in B cells and in subsets of B-cell lymphomas. Blood 92, 1308-1316.

Kroll, T. G., Sarraf, P., Pecciarini, L., Chen, C. J., Mueller, E., Spiegelman, B. M., and Fletcher, J. A. (2000). PAX8-PPARgammal fusion oncogene in human thyroid carcinoma [corrected]. Science 289, 1357-1360.

Kubic, J. D., Young, K. P., Plummer, R. S., Ludvik, A. E., and Lang, D. (2008). Pigmentation PAX-ways: the role of Pax3 in melanogenesis, melanocyte stem cell maintenance, and disease. Pigment Cell Melanoma Res. 21, 627-645.

Lai, H. C., Lin, Y. W., Huang, T. H., Yan, P., Huang, R. L., Wang, H. C., Liu, J., Chan, M. W., Chu, T. Y., Sun, C. A., Chang, C. C., and Yu, M. H. (2008). Identification of novel DNA methylation markers in cervical cancer. Int. J. Cancer 123, 161-167.

Lang, D., Lu, M. M., Huang, L., Engleka, K. A., Zhang, M., Chu, E. Y., Lipner, S., Skoultchi, A., Millar, S. E., and Epstein, J. A. (2005). Pax3 functions at a nodal point in melanocyte stem cell differentiation. Nature 433, 884-887.

Lang, D., Mascarenhas, J. B., Powell, S. K., Halegoua, J., Nelson, M., and Ruggeri, B. A. (2008). PAX6 is expressed in pancreatic adenocarcinoma and is downregulated during induction of terminal differentiation. Mol. Carcinog. 47, 148-156.

Lee, J. C., Sharma, M., Lee, Y. H., Lee, N. H., Kim, S. Y., Yun, J. S., Nam, S. Y., Hwang, P. H., Jhee, E. C., and Yi, H. K. (2008). Pax9 mediated cell survival in oral squamous carcinoma cell enhanced by c-myb. Cell Biochem. Funct. 26, 892-899.

Leiper, L. J., Ou, J., Walczysko, P., Kucerova, R., Lavery, D. N., West, J. D., and Collinson, J. M. (2009). Control of patterns of corneal innervation by Pax6. Invest. Ophthalmol. Vis. Sci. 50, 1122-1128.

Li, C. G., Nyman, J. E., Braithwaite, A. W., and Eccles, M. R. (2011a). PAX8 promotes tumor cell growth by transcriptionally regulating E2F1 and stabilizing RB protein. Oncogene 30, 4824-4834.

Li, L., Li, B., Zhang, H., Bai, S., Wang, Y., Zhao, B., and Jonas, J. B. (2011b). Lentiviral vectormediated PAX6 overexpression promotes growth and inhibits apoptosis of human retinoblastoma cells. Invest. Ophthalmol. Vis. Sci. 52, 8393-8400.
Little, M. H., and Bertram, J. F. (2009). Is there such a thing as a renal stem cell? J. Am. Soc. Nephrol. 20, 2112-2117.

Liu, W., Li, X., Chu, E. S., Go, M. Y., Xu, L., Zhao, G., Li, L., Dai, N., Si, J., Tao, Q., Sung, J. J., and Yu, J. (2011). Paired box gene 5 is a novel tumor suppressor in hepatocellular carcinoma through interaction with p53 signaling pathway. Hepatology 53, 843-853.

Lu, J., Li, G., Lan, M. S., Zhang, S., Fan, W., Wang, H., and Lu, D. (2007). Pax4 paired domain mediates direct protein transduction into mammalian cells. Endocrinology 148, 5558-5565

Luu, V. D., Boysen, G., Struckmann, K., Casagrande, S., Von Teichman, A., Wild, P. J., Sulser, T., Schraml, P., and Moch, H. (2009). Loss of VHL and hypoxia provokes PAX2 up-regulation in clear cell renal cell carcinoma. Clin. Cancer Res. 15, 3297-3304.

Maeshima,A., Maeshima, K., Nojima,Y., and Kojima, I. (2002). Involvement of Pax-2 in the action of activin A on tubular cell regeneration. J. Am. Soc. Nephrol. 13, 2850-2859.

Mascarenhas, J. B., Young, K. P., Littlejohn, E. L., Yoo, B. K., Salgia, R., and Lang, D. (2009). PAX6 is expressed in pancreatic cancer and actively participates in cancer progression through activation of the MET tyrosine kinase receptor gene. J. Biol. Chem. 284, 27524-27532.

Maulbecker, C. C., and Gruss, P. (1993). The oncogenic potential of Pax genes. EMBO J. 12, 2361-2367.

Mayes, D. A., Hu, Y., Teng, Y., Siegel, E., Wu, X., Panda, K., Tan, F., Yung, W. K., and Zhou, Y. H. (2006). PAX6 suppresses the invasiveness of glioblastoma cells and the expression of the matrix metalloproteinase-2 gene. Cancer Res. 66, 9809-9817.

Medic, S., and Ziman, M. (2010). PAX3 expression in normal skin melanocytes and melanocytic lesions (naevi and melanomas). PLoS ONE 5, e9977. doi:10.1371/journal.pone.0009977

Miller, D. J. (1999). What the cnidaria tell us about Pax gene evolution. Zool. Stud. 38, 367-372.

Mittag, J., Winterhager, E., Bauer, K., and Grummer, R. (2007). Congenital hypothyroid female pax8deficient mice are infertile despite thyroid hormone replacement therapy. Endocrinology 148, 719-725.

Miyamoto, T., Kakizawa, T., Ichikawa, K., Nishio, S., Kajikawa, S., and Hashizume, K. (2001). Expression of dominant negative form of PAX4 in human insulinoma. Biochem. Biophys. Res. Commun. 282, 34-40.

Moelans, C. B., Verschuur-Maes, A. H. and Van Diest, P. J. (2011). Frequent promoter hypermethylation of BRCA2, CDH13, MSH6, PAX5, PAX6 and WT1 in ductal carcinoma in situ and invasive breast cancer. $J$. Pathol. 225, 222-231.

Monte, N. M., Webster, K. A., Neuberg, D., Dressler, G. R., and Mutter, G. L. (2010). Joint loss of PAX2 and PTEN expression in endometrial precancers and cancer. Cancer Res. 70, 6225-6232.

Muratovska, A., Zhou, C., He, S. Goodyer, P., and Eccles, M. R. (2003). Paired-Box genes are frequently expressed in cancer and often required for cancer cell survival. Oncogene 22, 7989-7997.

Nakamura, H. (2001). Regionalization of the optic tectum: combinations of gene expression that define the tectum. Trends. Neurosci. 24 32-39.

Nutt, S. L., Urbanek, P., Rolink, A. and Busslinger, M. (1997). Essential functions of Pax5 (BSAP) in pro-B cell development: difference between fetal and adult B lymphopoiesis and reduced V-to-DJ recombination at the $\operatorname{IgH}$ locus. Genes Dev. 11, 476-491.

$\mathrm{Ou}, \mathrm{J}$., Lowes, C., and Collinson, J. M. (2010). Cytoskeletal and cell adhesion defects in wounded and Pax6士 corneal epithelia. Invest. Ophthalmol. Vis. Sci. 51, 1415-1423.

Ozcan, A., Shen, S. S., Hamilton, C. Anjana, K., Coffey, D., Krishnan, B. and Truong, L. D. (2011). PAX 8 expression in non-neoplastic tissues, primary tumors, and metastatic tumors: a comprehensive immunohistochemical study. Mod. Pathol. 24 751-764.

Park, C., Lee, I., and Kang, W. K. (2006). E2F-1 is a critical modulator of cellular senescence in human cancer. Int J. Mol. Med. 17, 715-720.

Peters, H., Doll, U., and Niessing, J. (1995). Differential expression of the chicken Pax-1 and Pax-9 gene: in situ hybridization and immunohistochemical analysis. Dev. Dyn. 203, 1-16.

Peters, H., Schuster, G., Neubuser, A., Richter, T., Hofler, H., and Balling, R. (1997). Isolation of the $\operatorname{Pax} 9$ cDNA from adult human esophagus. Mamm. Genome 8, 62-64.

Pinto, G. R., Clara, C. A., Santos, M. J., Almeida, J. R., Burbano, R. R., Rey, J. A., and Casartelli, C. (2007). Mutation analysis of gene PAX6 in human gliomas. Genet. Mol. Res. 6, 1019-1025.
Proulx, M., Cayer, M. P., Drouin, M. Laroche, A., and Jung, D. (2010). Overexpression of PAX5 induces apoptosis in multiple myeloma cells. Int. J. Hematol. 92, 451-462.

Qin, X. Q., Livingston, D. M., Kaelin, W. G. Jr., and Adams, P. D. (1994). Deregulated transcription factor E2F-1 expression leads to S-phase entry and p53-mediated apoptosis. Proc. Natl. Acad. Sci. U.S.A. 91, 10918-10922.

Ramaesh, T., Ramaesh, K., Leask, R. Springbett, A., Riley, S. C., Dhillon, B., and West, J. D. (2006). Increased apoptosis and abnormal woundhealing responses in the heterozygous Pax6 \pm mouse cornea. Invest. Ophthalmol. Vis. Sci. 47, 1911-1917.

Ramaesh, T., Ramaesh, K., Martin Collinson, J., Chanas, S. A., Dhillon B., and West, J. D. (2005). Developmental and cellular factors underlying corneal epithelial dysgenesis in the Pax $6 \pm$ mouse model of aniridia. Exp. Eye Res. 81, 224-235.

Rath, M. F., Bailey, M. J., Kim, J.S., Coon, S. L., Klein, D. C., and Moller, M. (2009a). Developmental and daily expression of the Pax 4 and Pax6 homeobox genes in the rat retina: localization of Pax4 in photoreceptor cells. J. Neurochem. 108, 285-294.

Rath, M. F., Bailey, M. J., Kim, J. S., Ho, A. K., Gaildrat, P., Coon, S. L., Moller, M., and Klein, D. C. (2009b). Developmental and diurnal dynamics of Pax4 expression in the mammalian pineal gland: nocturnal down-regulation is mediated by adrenergic-cyclic adenosine $3^{\prime}, 5^{\prime}$-monophosphate signaling. Endocrinology 150, 803-811.

Relaix, F., Montarras, D., Zaffran, S., Gayraud-Morel, B., Rocancourt, D., Tajbakhsh, S., Mansouri, A. Cumano, A., and Buckingham, M. (2006). Pax3 and Pax7 have distinct and overlapping functions in adult muscle progenitor cells. J. Cell Biol. 172, 91-102.

Rieck, S., White, P., Schug, J., Fox, A. J., Smirnova, O., Gao, N., Gupta, R. K. Wang, Z. V., Scherer, P. E., Keller, M. P., Attie, A. D., and Kaestner, K. H. (2009). The transcriptional response of the islet to pregnancy in mice. Mol. Endocrinol. 23, 1702-1712.

Ritz-Laser, B., Estreicher, A., Gauthier, B., and Philippe, J. (2000). The paired homeodomain transcription factor Pax-2 is expressed in the endocrine pancreas and transactivates the glucagon gene promoter. J. Biol. Chem. 275, 32708-32715.

Robson, E. J., He, S. J., and Eccles, M. R. (2006). A PANorama of PAX genes 
in cancer and development. Nat. Rev. Cancer 6, 52-62.

Roh, M. H., Yassin, Y., Miron, A., Mehra, K. K., Mehrad, M., Monte, N. M., Mutter, G. L., Nucci, M. R., Ning, G., Mckeon, F. D., Hirsch, M. S., Wa, X., and Crum, C. P. (2010). Highgrade fimbrial-ovarian carcinomas are unified by altered p53, PTEN and PAX2 expression. Mod. Pathol. 23, 1316-1324.

Salem, C. E., Markl, I. D., Bender, C. M., Gonzales, F. A., Jones, P. A., and Liang, G. (2000). PAX6 methylation and ectopic expression in human tumor cells. Int. J. Cancer 87, 179-185.

Sansom, S. N., Griffiths, D. S., Faedo, A., Kleinjan, D. J., Ruan, Y., Smith, J., Van Heyningen, V., Rubenstein, J. L., and Livesey, F. J. (2009). The level of the transcription factor Pax6 is essential for controlling the balance between neural stem cell self-renewal and neurogenesis. PLoS Genet. 5, e1000511. doi:10.1371/journal.pgen.1000511

Sanz, E., Alvarez-Mon, M., Martinez, A. C., and De La Hera, A. (2003). Human cord blood CD34+Pax-5+ B-cell progenitors: single-cell analyses of their gene expression profiles. Blood 101, 3424-3430.

Scholl, F. A., Kamarashev, J., Murmann, O. V., Geertsen, R., Dummer, R., and Schafer, B. W. (2001). PAX3 is expressed in human melanomas and contributes to tumor cell survival. Cancer Res. 61, 823-826.

Silberstein, G. B., Dressler, G. R., and Van Horn, K. (2002). Expression of the PAX2 oncogene in human breast cancer and its role in progesteronedependent mammary growth. Oncogene 21, 1009-1016.

Sivak, J. M., Mohan, R., Rinehart, W. B., Xu, P. X., Maas, R. L., and Fini, M. E. (2000). Pax-6 expression and activity are induced in the reepithelializing cornea and control activity of the transcriptional promoter for matrix metalloproteinase gelatinase B. Dev. Biol. 222, 41-54.

Stoykova, A., and Gruss, P. (1994). Roles of Pax-genes in developing and adult brain as suggested by expression patterns. J. Neurosci. 14, 1395-1412.

Suda, N., Ogawa, T., Kojima, T., Saito, C., and Moriyama, K. (2011). Nonsyndromic oligodontia with a novel mutation of PAX9. J. Dent. Res. 90, 382-386.

Thomas, T., Nowka, K., Lan, L., and Derwahl, M. (2006). Expression of endoderm stem cell markers: evidence for the presence of adult stem cells in human thyroid glands. Thyroid 16, 537-544.

Tong, G. X., Chiriboga, L., HameleBena, D., and Borczuk, A. C. (2007). Expression of PAX2 in papillary serous carcinoma of the ovary: immunohistochemical evidence of fallopian tube or secondary Mullerian system origin? Mod. Pathol. 20, 856-863.

Tong, G. X., Melamed, J., Mansukhani, M., Memeo, L., Hernandez, O., Deng, F. M., Chiriboga, L., and Waisman, J. (2006). PAX2: a reliable marker for nephrogenic adenoma. Mod. Pathol. 19, 356-363.

Tong, G. X., Memeo, L., Colarossi, C., Hamele-Bena, D., Magi-Galluzzi, C., Zhou, M., Lagana, S. M., Harik, L., Oliver-Krasinski, J. M., Mansukhani, M., Falcone, L., Hibshoosh, H., and O'Toole, K. (2011). PAX8 and PAX2 immunostaining facilitates the diagnosis of primary epithelial neoplasms of the male genital tract. Am. J. Surg. Pathol. 35, 1473-1483.

Tong, G. X., Yu, W. M., Beaubier, N. T., Weeden, E. M., HameleBena, D., Mansukhani, M. M., and O’Toole, K. M. (2009). Expression of PAX8 in normal and neoplastic renal tissues: an immunohistochemical study. Mod. Pathol. 22, 1218-1227.
Urbanek, P., Wang, Z. Q., Fetka, I. Wagner, E. F., and Busslinger, M. (1994). Complete block of early B cell differentiation and altered patterning of the posterior midbrain in mice lacking Pax5/BSAP. Cell 79, 901-912.

Vidal, L. J., Perry, J. K., Vouyovitch, C. M., Pandey, V., Brunet-Dunand, S. E., Mertani, H. C., Liu, D. X., and Lobie, P. E. (2010). PAX5alpha enhances the epithelial behavior of human mammary carcinoma cells. Mol. Cancer Res. 8, 444-456.

Vorobyov, E., and Horst, J. (2006). Getting the proto-Pax by the tail. J. Mol. Evol. 63, 153-164.

Wallin, J., Eibel, H., Neubuser, A., Wilting, J., Koseki, H., and Balling, R. (1996). Paxl is expressed during development of the thymus epithelium and is required for normal $\mathrm{T}$ cell maturation. Development 122 , 23-30.

Wang, Q., Fang, W. H., Krupinski, J., Kumar, S., Slevin, M., and Kumar, P. (2008). Pax genes in embryogenesis and oncogenesis. J. Cell. Mol. Med. 12, 2281-2294.

Watanabe, A., Takeda, K., Ploplis, B., and Tachibana, M. (1998). Epistatic relationship between Waardenburg syndrome genes MITF and PAX3. Nat. Genet. 18, 283-286.

Wu, H., Chen, Y., Liang, J., Shi, B. Wu, G., Zhang, Y., Wang, D., Li, R., Yi, X., Zhang, H., Sun, L., and Shang, Y. (2005). Hypomethylationlinked activation of PAX2 mediates tamoxifen-stimulated endometrial carcinogenesis. Nature 438 , 981-987.

Zannini, M., Francis-Lang, H., Plachov D., and Di Lauro, R. (1992). Pax8 , a paired domain-containing protein, binds to a sequence overlapping the recognition site of a homeodomain and activates transcription from two thyroid-specific promoters. Mol. Cell. Biol. 12, 4230-4241.

Zhang, X., Huang, C. T., Chen, J. Pankratz, M. T., Xi, J., Li, J., Yang,
Y., Lavaute, T. M., Li, X. J., Ayala, M., Bondarenko, G. I., Du, Z. W., Jin, Y., Golos, T. G., and Zhang, S. C. (2010). Pax6 is a human neuroectoderm cell fate determinant. Cell Stem Cell 7, 90-100.

Zhou, Y. H., Hu, Y., Mayes, D., Siegel, E., Kim, J. G., Mathews, M. S., Hsu, N., Eskander, D., Yu, O., Tromberg, B. J., and Linskey, M. E. (2010). PAX6 suppression of glioma angiogenesis and the expression of vascular endothelial growth factor A. J. Neurooncol. 96, 191-200.

Zhou, Y. H., Wu, X., Tan, F., Shi, Y. X., Glass, T., Liu, T. J., Wathen, K., Hess, K. R., Gumin, J., Lang, F., and Yung, W. K. (2005). PAX6 suppresses growth of human glioblastoma cells. J. Neurooncol. 71, 223-229.

Zong, X., Yang, H., Yu, Y., Zou, D., Ling, Z., He, X., and Meng, X. (2011). Possible role of Pax- 6 in promoting breast cancer cell proliferation and tumorigenesis. BMB Rep. 44, 595-600.

Conflict of Interest Statement: The authors declare that the research was conducted in the absence of any commercial or financial relationships that could be construed as a potential conflict of interest.

Received: 14 October 2011; accepted: 09 January 2012; published online: 31 January 2012.

Citation: $\mathrm{Li} C \mathrm{CG}$ and Eccles $\mathrm{MR}$ (2012) PAX genes in cancer; friends or foes? Front. Gene. 3:6. doi: 10.3389/fgene.2012.00006

This article was submitted to Frontiers in Cancer Genetics, a specialty of Frontiers in Genetics.

Copyright $(\odot 2012$ Li and Eccles. This is an open-access article distributed under the terms of the Creative Commons Attribution Non Commercial License, which permits non-commercial use, distribution, and reproduction in other forums, provided the original authors and source are credited. 